\title{
Comparison of Abnormal Lipid Profile in Normotensive and Hypertensive Women during Pregnancy and its Significance
}

\author{
Shobhan Kumar ${ }^{1}$ and Kavitha B $^{2 *}$ \\ ${ }^{1}$ Department of General Medicine, Mamata Medical College, India \\ ${ }^{2}$ Department of Obstetrics and Gynaecology, Mamata Medical College, India
}

Submission: September 09, 2017 ; Published: January 05, 2018

*Corresponding author: Kavitha B, Department of Obstetrics and Gynaecology, Mamata medical college, India, Tel: +91 9985237518;

Email: kavithabakshi@yahoo.co.in

Abstract

Background: Abnormal lipid profiles and reactive species may have role in the promotion of oxidative stress and vascular dysfunction seen in hypertensive disorders complicating pregnancy.

Aim: To detect and compare abnormal lipid profile in normotensive and hypertensive women during pregnancy. To find its significance in relation to maternal and perinatal outcome.

Material and methods: Study was conducted at Mamata general hospital, Khammam, Telangana state, India, over 3 years from $2012-2015$. Study group consisted of 150 pregnant women divided into three groups of 50 each - group-A: normotensive women, group B: women with mild hypertension ( $\mathrm{BP}<160 / 110 \mathrm{~mm}$ of $\mathrm{Hg}$ ) and group C: women with severe hypertension (BP>160/110 mm of $\mathrm{Hg}$ ).

Results: There was no significant difference in mean age (about 23years) between the study groups and most of them were primigravidas. Mean gestional age at delivery was significantly less in groups B and C compared to group A, correlating with high mean systolic (SBP) and diastolic blood pressure (DBP). All lipid parameters were abnormal in maximum number of patients in groups B and C, which correlated well with number of women having maternal and perinatal complications. Mean values of all lipid paramaters were also abnormal in both hypertensive groups.

Conclusion: The present study concludes that abnormal lipid profile may have an effect on patho-physiology of hypertension in pregnancy and its correlation with severity.

Keywords: Lipid profile; Hypertensive disorders; Maternal and perinatal complications

Abbreviations: BP: Blood Pressure; SBP: Systolic Blood Pressure; DBP: Diastolic Blood Pressure; HDL: High Density Lipoprotein; LDL: Low Density Lipoprotein; SD: Standard Deviation; HELLP: Hemolysis, Elevated Liver Enzymes Low Platelet Count; IUGR: Intra-Uterine Growth Restriction; PPH: Postpartum Haemorrhage

\section{Introduction}

Abnormal lipid metabolism contributes to the promotion of oxidative stress and vascular dysfunction seen in hypertensive disorders complicating pregnancy. Especially the atherogenic small low density lipoproteins (LDL) and vascular adhesion molecules are in association with hyper lipidemia in preeclampsia [1]. Although there is growing evidence indicating that risk of preeclampsia is increased in women with elevated levels of LDL and Triglycerides [2], the causal relationship of lipid peroxidation in the pathogenesis of preeclampsia is not clear.
The gestational hypertension associated with abnormal serum lipid profile shown in many studies is highly suggestive of lipid profile as a diagnostic tool in pregnancy induced hypertension. Abnormal lipid profile leads to decrease in prostaglandin: thromboxane A2 ratio. So this study was undertaken to evaluate abnormal lipid profile in hypertension in pregnancy and correlate with maternal and perinatal outcome.

\section{Material and Methods}

Study group consisted of 150 pregnant women divided into three groups of 50 each - group-A: normotensive women, group-B: 
women with mild hypertension $(\mathrm{BP}<160 / 110 \mathrm{~mm}$ of $\mathrm{Hg})$ and group-C: women with severe hypertension (BP>160/110mm of $\mathrm{Hg}$ ). Study was conducted at Mamata general hospital, Khammam, Telangana state, India, over 3 years from 2012- 2015.

Exclusion criteria: Pregnant women with other medical disorders like diabetes, chronic hypertension, renal failure, liver disorders, thyroid disease, and severe anemia were excluded.

\section{Procedure}

$5 \mathrm{ml}$ of venous blood was drawn from study subjects after overnight fasting for $8-12 \mathrm{hrs}$. Serum was separated by centrifugation and evaluated for
a. Total cholesterol,
b. Trigycerides,
c. High density lipoprotein (HDL) and
d. Low density lipoprotein (LDL).

Table 1: Base line characters of study Population.

\section{Stastical analysis}

Descriptive and inferential statistics were used to summarize the data. In descriptive statistics, Mean and standard deviation were used. In inferential statistics, Z-test of means was used and p-value calculated.

\section{Results}

Lipid profile in all the three groups was studied. Baseline characters of study population are seen in Table 1. Mean age of women in groups-A, B and C was 23.12 \pm 3.39 (SD), $22.96 \pm 4.31$ (SD) and $23.40 \pm 4.7$ (SD) respectively with p-value $>0.05$ (not significant). Mean gestational age at delivery was $37.92 \pm 1.94(\mathrm{SD}), \quad 35.61 \pm 3.1(\mathrm{SD})$ and $33.6 \pm 2.71(\mathrm{SD})$ respectively with significant $\mathrm{p}$-value $=0.00001$. Most women were primigravidas- $60 \%, 72 \%$ and $54 \%$ respectively. Mean systolic blood pressure (SBP) was 116.08 \pm 7.77 (SD), 144.29 \pm 6.45 (SD) and $166.6 \pm 8.25(\mathrm{SD})$ respectively with highly significant $\mathrm{p}$-value $=0.000001$. Mean diastolic blood pressure (DBP) was $76.08 \pm 4.93(\mathrm{SD}), 94.08 \pm 5.74(\mathrm{SD})$ and116.8 \pm 11.33 respectively with highly significant $\mathrm{p}$-value $=0.0000001$.

\begin{tabular}{|c|c|c|c|c|}
\hline Base line characters & Group “A” & Group “B” & Group “C” & P-value \\
\hline Mean age & $23.12 \pm 3.39$ (S.D) & $22.96 \pm 4.31$ (S.D) & $23.40 \pm 4.7$ (S.D) & $>0.05$ (NS) \\
\hline Mean Gestational Age & $37.92 \pm 1.94$ (S.D) & $35.61 \pm 3.10$ (S.D) & $33.6 \pm 2.71$ (S.D) & 0.00001 (S) \\
\hline Gravida & Primi $60 \%$ & Primi $72 \%$ & Primi $54 \%$ & \\
\hline Mean SBP & $116.08 \pm 7.77$ (S.D) & $144.29 \pm 6.45$ (S.D) & $166.6 \pm 18.25$ (S.D) & $0.000001($ S) \\
\hline Mean DBP & $76.08 \pm 4.93$ (S.D) & $94.08 \pm 5.74$ (S.D) & $116.8 \pm 11.33$ (S.D) & $0.0000001($ S) \\
\hline
\end{tabular}

SBP: Systolic Blood Pressure

DBP: Diastolic Blood Pressure

\section{SD: Standard Deviation}

Table 2 shows frequency distribution of abnormal lipid profile in the study groups. High total cholesterol was present in $4 \%, 90 \%$ and $98 \%$ of groups A, B and C respectively. Abnormal

Table 2: Frequency Distribution of abnormal Lipid Profile.

\begin{tabular}{|c|c|c|c|}
\hline Lipid Parameters & Group “A” & Group “B” & Group "C” \\
\hline Total Cholesterol>200mg/dl & $2(4 \%)$ & $45(90 \%)$ & $49(98 \%)$ \\
\hline Triglycerides>150mg/dl & $3(6 \%)$ & $45(90 \%)$ & $50(100 \%)$ \\
\hline HDL $<45 \mathrm{mg} / \mathrm{dl}$ & $12(24 \%)$ & $41(82 \%)$ & $45(90 \%)$ \\
\hline LDL $>130 \mathrm{mg} / \mathrm{dl}$ & $2(4 \%)$ & $38(76 \%)$ & $43(86 \%)$ \\
\hline
\end{tabular}

\section{HDL: High Density Lipoprotein}

\section{LDL: Low Density Lipoprotein}

Abnormal mean lipid values in each group are shown in (Table 3). Mean total cholesterol was $179.04 \pm 14.82$ (SD), $221.16 \pm 24$ (SD) and 262.9 \pm 28.06 (SD) in groups A, B and C respectively. Mean triglyceride was $136.94 \pm 15.94(\mathrm{SD}), 185.65 \pm 48.26(\mathrm{SD})$ and 237.68 \pm 44.36 (SD) respectively. Mean HDL was 48.61 \pm 4.72 (SD), $42.31 \pm 3.9(\mathrm{SD})$ and $38.94 \pm 4.09$ (SD) respectively. Mean LDL was $115.35 \pm 11.74$ (SD), $\quad 145.43 \pm 23.16$ (SD) and166.64 \pm 39.9 (SD) respectively. All abnormal mean lipid values had significant p-values $<0.001$. triglycerides were seen in 6\%, 90\% and $100 \%$ respectively. $12 \%$, $82 \%$ and $90 \%$ had abnormal HDL levels and $4 \%, 76 \%$ and $86 \%$ had abnormal LDL values respectively.
Table 4 show correlation of abnormal lipid profile in groups $\mathrm{B}$ and $\mathrm{C}$ with maternal and fetal complications. Group-A was not correlated as frequency distribution of abnormal lipids was less and complications were negligible. In women with high total cholesterol, maternal complications were seen in $6.66 \%$ and $53.35 \%$ of groups B and C respectively, while perinatal complications were seen in $75.5 \%$ and $97.9 \%$ respectively. In women with high triglyceride, maternal complications were $6.66 \%$ and $50 \%$ in B and C groups, while perinatal complications 
were $75.5 \%$ and $98 \%$ respectively. With abnormal HDL, maternal complications were $7.3 \%$ and $80.48 \%$ in groups-B and C, while perinatal complications were $90.2 \%$ and $97.7 \%$ respectively.
With abnormal LDL, maternal complications were $7.9 \%$ and $60.5 \%$ in B and $\mathrm{C}$ groups, while perinatal complications were $34.2 \%$ and $97.6 \%$ respectively.

Table 3: Distribution of abnormal mean lipid values.

\begin{tabular}{|c|c|c|c|c|}
\hline Abnormal Means & Group "A" & Group "B" & Group "C" & P-value \\
\hline Total Cholesterol & $179.04 \pm 14.82($ S.D) & $221.16 \pm 24.1$ (S.D) & $262.9 \pm 28.06$ (S.D) & $<0.001(\mathrm{~S})$ \\
\hline Triglyceride & $136.94 \pm 15.94($ S.D) & $185.65 \pm 48.26(S)$ & $237.68 \pm 44.36$ (S.D) & $<0.001(\mathrm{~S})$ \\
\hline Mean HDL & $48.61 \pm 4.72$ (S.D) & $42.31 \pm 3.9($ S.D $)$ & $38.94 \pm 4.09$ (S.D) & $<0.001(S)$ \\
\hline LDL & $115.35 \pm 11.74($ S.D) & $145.43 \pm 23.16$ (S.D) & $166.64 \pm 37.9$ (S.D) & $<0.001(\mathrm{~S})$ \\
\hline
\end{tabular}

Table 4: Correlation of abnormal lipid profile with maternal and perinatal complications.

\begin{tabular}{|c|c|c|c|c|c|c|}
\hline \multirow{2}{*}{ Abnormal Lipids } & \multicolumn{4}{|c|}{ Group “B” } & \multicolumn{2}{c|}{ Group “C” } \\
\cline { 2 - 7 } & Total* & $\begin{array}{c}\text { Maternal } \\
\text { Complications }\end{array}$ & $\begin{array}{c}\text { Perinatal } \\
\text { Complications }\end{array}$ & Total* & $\begin{array}{c}\text { Maternal } \\
\text { Complications }\end{array}$ & $\begin{array}{c}\text { Perinatal } \\
\text { Complications }\end{array}$ \\
\hline $\begin{array}{c}\text { Total Cholesterol } \\
>200 \mathrm{mg} / \mathrm{dl}\end{array}$ & 45 & $3(6.6 \%)$ & $34(75.5 \%)$ & 49 & $24(53.35 \%)$ & $48(97.9 \%)$ \\
\hline $\begin{array}{c}\text { Triglycerides } \\
>150 \mathrm{mg} / \mathrm{dl}\end{array}$ & 45 & $3(6.6 \%)$ & $34(75.5 \%)$ & 50 & $25(50 \%)$ & $51(98.1 \%)$ \\
\hline HDL $<45 \mathrm{mg} / \mathrm{dl}$ & 41 & $3(7.3 \%)$ & $37(90.2 \%)$ & 45 & $33(80.4 \%)$ & $44(97.7 \%)$ \\
\hline LDL $>130 \mathrm{mg} / \mathrm{dl}$ & 38 & $3(7.8 \%)$ & $32(84.2 \%)$ & 43 & $23(60.5 \%)$ & $42(97.6 \%)$ \\
\hline
\end{tabular}

*Total women with abnormal lipid profile.

\section{Discussion}

In above study there was no significant difference in mean age (about 23years) between the study groups and most of them were primigravidas. This was similar to a study by Josephine Latha P3 (about 24 years) who concluded that there was no relation of mean age to hypertension in pregnancy. But study by Gohil J T2 showed that hypertensive disorders in pregnancy were more common at younger age (19-22y) and in primigravidas [3].

In present study, mean gestational age at delivery was significantly less in groups B and C compared to group A with least in group $\mathrm{C}$ correlating with mean systolic (SBP) and diastolic blood pressure (DBP), which were significantly higher in groups Band $\mathrm{C}$ with highest in group $\mathrm{C}$ (Table 1). So, as the severity of hypertension increased, gestational age decreased. This correlation was not observed by Meena Mittal [4].

All lipid parameters were abnormal in maximum number of patients in groups B and C while only a few women in group A had abnormal profile in present study (Table 2). This correlated well with number of women having maternal and perinatal complications, especially in group C. But in group B, although number of women with perinatal complications correlated well with those having abnormal lipid profile, maternal complications were comparatively fewer (Table 4).

In group A there were no maternal complications. In group $\mathrm{B}$, pregnancies were complicated by abruption placentae in $2 \%$ and atonic postpartum haemorrhage in $4 \%$ of women. Maternal complications seen in group C were HELLP syndrome (14\%), acute renal failure (4\%), pulmonary edema (10\%), disseminated intravascular coagulation $(2 \%)$ and maternal death $(8 \%)$, in addition to abruption (14\%) and atonic PPH (4\%). These were comparable to a study by Edgar M Ndaboine5, except the incidence of HELLP syndrome which was quite high (50.9\%) [5].

In group $\mathrm{A}$, there were a few perinatal complications like IUGR, preterm- ( $8 \%$ each) and fetal distress (10\%). In groups B and C, complications like IUGR $(36 \%, 68 \%)$, prematurity $(48 \%$, $70 \%)$, intra-uterine death $(12 \%, 24 \%)$, fetal distress (34\%each), birth asphyxia $(14 \%, 36 \%)$, respiratory distress syndrome $(22 \%$, $30 \%)$, neonatal sepsis (2\%each), neonatal death (14\%each) were more. Similarly correlation of perinatal complications, especially IUGR, with hypertriglyceridemia was also done by D S Mshelia [6], who suggested that this could be a compensation pathway to counter uteroplacental hypoperfusion in order to enhance fatty acid transfer the fetus.

In present study, mean values of all lipid parameters were abnormal in both hypertensive groups- $\mathrm{B}$ and $\mathrm{C}$ compared to group A, with the degree of abnormality correlating well with the severity of hypertension (Table 3). This was similar to a study by Gohil [2], where dyslipidemia in the form of raised total cholesterol, triglycerides, LDL, VLDL and decreased HDL were conspicuously evident in pre-eclamptic subjects compared to normotensive pregnant women. In a study by Jayante De [7], preeclampsia group was associated with rise in triglycerides and VLDL and fall in HDL, while eclampsia group showed significant rise in LDL and fall in HDL. But there was no direct relationship between triglyceride levels and severity of pre-eclampsia in a study by Mikhail [8].

\section{Conclusion}

Hyperlipidemia is significantly evident in hypertension complicating pregnancy and may play an important role in its patho-physiology by promoting oxidative stress leading to 
vascular dysfunction. In present study increase in lipid levels parallelled with severity of hypertension and its effect on maternal and perinatal complications.

\section{References}

1. Qiu C, Phung TT, Vadachkoria S, Muy-RM, Sanchez SE, et al. (2006) Oxidized low-density lipoprotein (Oxidized LDL) and the risk of preeclampsia. Physiol Res 55(5): 491-500.

2. Gohil JT, Patel PK, Gupta P (2011) Estimation of lipid profile in subjects of preeclampsia. J Obstet Gynaecol India 61(4): 399-403.

3. Latha PJ, Ganesan S (2010) Evaluation of serum uric acid and lipid profile in preeclampsia and eclampsia. Faridpur Med Coll J 5: 56-59.

4. Mittal M, Kulkarni CV, Panchonia A, Mittal RK (2014) Evaluation of serum lipid profile in cases of preeclampsia and eclampsia. Int J Reprod Contracept Obstet Gynaecol 3(3): 732-734.

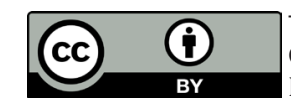

This work is licensed under Creative Commons Attribution 4.0 Licens

DOI: 10.19080/JGWH.2018.08.555728
5. Ndaboine EM, Kihunrwa A, Rumanyika R, Im HB, Massinde AN (2012) Maternal and perinatal outcomes among eclamptic patients admitted to Bugando medical centre, Mwanza, Tanzania. Afr J Reprod Health 16(1): 35-41.

6. Mshelia DS, Kullima A, Kawuwa MB, Mamza YP, Habu SA, et al. (2010) The use of plasma lipid and lipoprotein ratios in interpreting the hyperlipidemia of pregnancy. J Obstet Gynaecol 30: 804-808.

7. Jayanta De, Ananda M, Pradip KS (2016) Study of serum lipid profile in PIH. Indian J Clin Biochem 21(2): 165.

8. Mikhail MS, Basu J, Palan PR, Furgiuda J, Ronney SL, et al. (1995) Lipid profile in women with preeclampsia: relationship between plasma triglyceride levels and severity of preeclampsia. J Assoc Acad Minor Phys 6(1): 43-45.

\begin{tabular}{l} 
Your next submission with Juniper Publishers \\
will reach you the below assets \\
- Quality Editorial service \\
- Swift Peer Review \\
- Reprints availability \\
- E-prints Service \\
- Manuscript Podcast for convenient understanding \\
- Global attainment for your research \\
- Manuscript accessibility in different formats \\
( Pdf, E-pub, Full Text, Audio) \\
- Unceasing customer service \\
Track the below URL for one-step submission \\
https://juniperpublishers.com/online-submission.php \\
\hline
\end{tabular}

